УДК

\title{
СИНТЕЗ И СВОЙСТВА ИНТЕРПОЛИМЕРНЫХ КОМПЛЕКСОВ НА ОСНОВЕ ХИТОЗАНА И СУЛЬФАТИРОВАННОГО АРАБИНОГАЛАКТАНА
}

\author{
(C) 2020 г. Н. В. Слюсаренко ${ }^{a, *}$, Н. Ю. Васильева ${ }^{a}$, А. С. Казаченко ${ }^{b}$, \\ М. А. Герасимова ${ }^{a}$, А. С. Романченко ${ }^{b}$, Е. А. Слюсарева ${ }^{a}$ \\ ${ }^{a}$ Сибирский федеральный университет 660041 Красноярск, пр. Свободный, 79, Россия \\ b “Красноярский научный центр Сибирского отделения Российской академии наук”. \\ Институт химии и химической технологии \\ 660036 Красноярск, ул. Академгородок, 50/24, Россия \\ *e-mail:sci_box@mail.ru \\ Поступила в редакцию 25.07.2019 г. \\ После доработки 07.11.2019 г. \\ Принята к публикации 22.11.2019 г.
}

\begin{abstract}
Синтезированы стабильные в течение 30 дней интерполимерные комплексы на основе хитозана и арабиногалактана с различной степенью сульфатирования (7.7-40.8\%). Полученные комплексы охарактеризованы с помощью электронной сканирующей микроскопии, ИК-спектроскопии, динамического светорассеяния и электрофоретического измерения Ђ-потенциала. Основной механизм образования комплексов рассмотрен в терминах электростатического связывания полиионов. Новые комплексы имеют перспективу применения в качестве биосорбентов и систем доставки лекарств.
\end{abstract}

DOI: $10.31857 / \mathrm{S} 2308113920020059$

\section{ВВЕДЕНИЕ}

Среди природных полисахаридов хитозан продукт дезацетилирования хитина - занимает уникальное место. Он имеет поликатионную природу в кислых средах, биоразлагаем, обладает антибактериальным эффектом, биоадгезивными и заживляющими свойствами [1]. Формирование гидрофильных нестехиометрических интерполимерных комплексов (ИПК) на основе хитозана позволяет не только сохранить важные для биомедицины свойства полимера, но и дополнить их присущими частицам свойствами: подвижностью, увеличенной эффективной поверхностью, фильтрацией. Это дает возможность применять их в качестве биосорбентов нлн-редетв дөставжн ңекаретвенщнередетв [2-5]. Катионная природа хитозана позволяет формировать комплексы (в литературе их также называют полиэлектролитными комплексами) с различными анионными полисахаридами, например гепарином, каррагинанами, хондроитин сульфатом, гиалуронатом и другими [6-12]. Создание новых интерполимерных комплексов, выгодно сочетающих в себе свойства частиц и биополимеров, продолжается, а важным вопросом их практического применения является коллоидная стабильность.
В настоящей работе впервые исследована возможность создания нестехиометрических субмикронных интерполимерных комплексов на основе хитозана и сульфатированного арабиногалактана (САГ). Источником арабиногалактана в основном служит древесина лиственницы. Сульфатирование арабиногалактана значительно расширяет его границы применимости. Так, анионная активность позволяет формировать полиэлектролитные комплексы с поликатионами, а гиполипидемические и антикоагулянтные свойства дают возможность применять его как аналог гепариноидов или в качестве антимикробного агента [13, 14]. Совместное успешное использование указанных двух полисахаридов для тканевой инженерии было продемонстрировано на примере создания высокопористых губок [15].

Свойства комплексов, полученных из арабиногалактана с разной степенью сульфатирования, изучены методами сканирующей электронной микроскопии и динамического рассеяния света, приведены результаты измерений ИК-спектров интерполимерных комплексов (размер и тенциал), а также исходных полимеров, образующих ИПК. Новые коллоидно-стабильные суб- 
Таблица 1. Характеристика сульфатированного арабиногалактана и ИПК

\begin{tabular}{|c|c|c|c|c|c|c|}
\hline \multirow{3}{*}{$\begin{array}{c}\text { Образец, } \\
\text { № }\end{array}$} & \multicolumn{2}{|c|}{$\begin{array}{c}\text { Сульфатированный } \\
\text { арабиногалактан }\end{array}$} & \multicolumn{4}{|c|}{ ИПК } \\
\hline & \multirow{2}{*}{$\begin{array}{l}\text { содержание } \\
\text { серы, мас. \% }\end{array}$} & \multirow{2}{*}{$\begin{array}{c}\text { степень } \\
\text { сульфатирования, } \\
\%\end{array}$} & \multicolumn{2}{|c|}{1 день после синтеза } & \multicolumn{2}{|c|}{30 дней после синтеза } \\
\hline & & & $\begin{array}{c}\text { размер, нм } \\
\text { (PDI) }\end{array}$ & $\begin{array}{c}\text { Һ-потенциал, } \\
\text { мВ }\end{array}$ & $\begin{array}{c}\text { размер, нм } \\
\text { (PDI) }\end{array}$ & 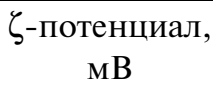 \\
\hline 1 & $13.5 \pm 0.2$ & $40.8 \pm 1$ & $\begin{array}{c}439 \pm 22 \\
(0.17)\end{array}$ & $40 \pm 2$ & $\begin{array}{c}305 \pm 18 \\
(0.19)\end{array}$ & $35 \pm 2$ \\
\hline 2 & $11.7 \pm 0.2$ & $32.4 \pm 1$ & $\begin{array}{c}424 \pm 18 \\
(0.12)\end{array}$ & $39 \pm 2$ & $\begin{array}{c}404 \pm 8 \\
(0.14)\end{array}$ & $34 \pm 3$ \\
\hline 3 & $12.1 \pm 0.2$ & $34.1 \pm 1$ & $\begin{array}{c}426 \pm 31 \\
(0.14)\end{array}$ & $38 \pm 2$ & $\begin{array}{c}377 \pm 11 \\
(0.08)\end{array}$ & $26 \pm 2$ \\
\hline 4 & $4.0 \pm 0.5$ & $8.1 \pm 1$ & $\begin{array}{c}334 \pm 11 \\
(0.20)\end{array}$ & $38 \pm 1$ & $\begin{array}{l}216 \pm 11 \\
\quad(0.12)\end{array}$ & $22 \pm 2$ \\
\hline 5 & $3.8 \pm 0.5$ & $7.7 \pm 1$ & $\begin{array}{c}328 \pm 7 \\
(0.20)\end{array}$ & $38 \pm 4$ & $\begin{array}{c}228 \pm 3 \\
(0.12)\end{array}$ & $32 \pm 3$ \\
\hline
\end{tabular}

микронные комплексы на основе хитозана и САГ являются перспективным биологически активным материалом, поскольку сочетают уникальные свойства входящих в его состав биополимеров [16-18].

\section{ЭКСПЕРИМЕНТАЛЬНАЯ ЧАСТЬ}

В качестве исходных полимеров для синтеза ИПК в работе использовали хитозан низковязкий из панциря креветки с молекулярной массой $M=(20-200) \times 10^{3}$ производства "Sigma-Aldrich":

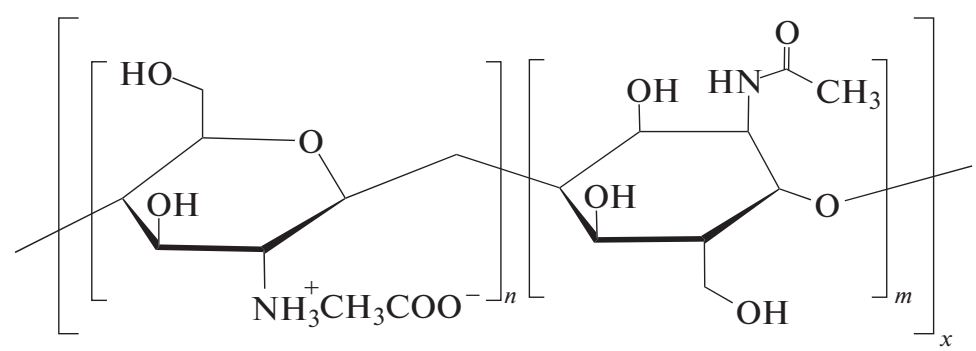

и арабиногалактан древесины лиственницы сибирской (Larix sibirica Ledeb.) со средней молекулярной массой $M \sim 17 \times 10^{3}$, предоставленный Об- ществом с ограниченной ответственностью “Химия древесины” (Россия) под наименованием препарата “ФиброларС” [19]:
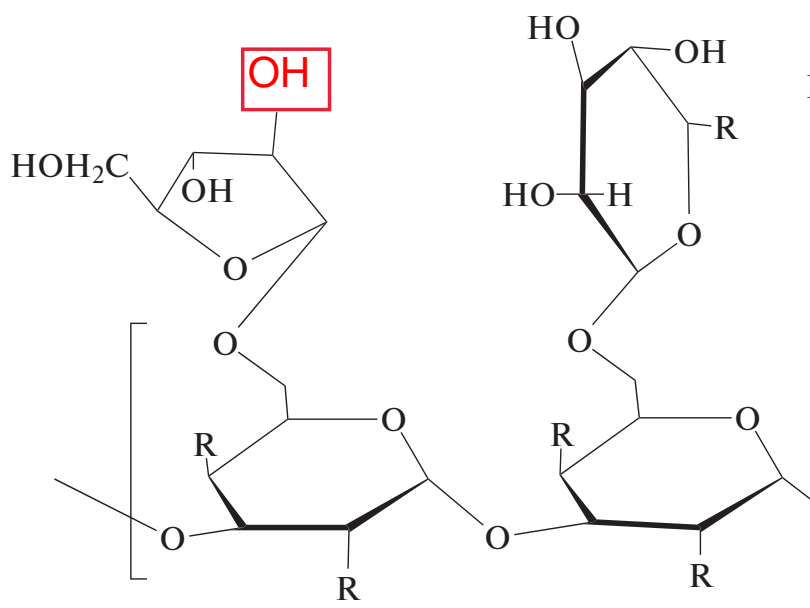<smiles>OCC1OC2OC1C(O)C2O</smiles><smiles>[R]OOS(=O)(=O)[NH2+][C-]</smiles>

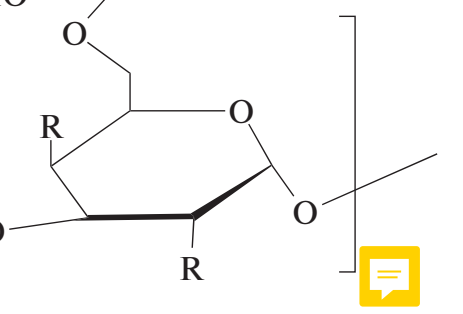


Синтез сульфатированного арабиногалактана осуществляли по методике [16] добавлением сульфаминовой кислоты в 1,4-диоксане или в диметилсульфоксиде в присутствии мочевины при различном температурном режиме и продолжительности процесса с последующим выделением САГ в виде аммониевой соли. Для удаления непрореагировавших реагентов продукт диализировали против воды в течение 8-10 ч, меняя воду каждый час. Диализ проводили с использованием целлюлозной мембраны Cellu Sep T1 (“Membrane Filtration Products Inc.”, США) с отсечкой по молекулярной массе $3.5 \times 10^{3}$. После диализа водный раствор САГ упаривали до полного высыхания (таблица 1, образцы 1, 3 и 4) или небольшого объема в вакууме на ротационном испарителе и осаждали в этанол. Образовавшийся осадок отфильтровывали, промывали на фильтре этанолом и высушивали на воздухе (образцы 2, 5). Образец 1 получали путем сульфатирования арабиногалактана в диметилсульфоксиде при температуре $85^{\circ} \mathrm{C}$ в течение 3 ч, образцы 2 и $3-$ в 1,4 -диоксане при $100^{\circ} \mathrm{C}$ также в течение 3 ч, а образцы 4 и $5-$ в диоксане при $85^{\circ} \mathrm{C}$ в течение 2 ч.

Содержание серы и степени сульфатирования арабиногалактана в образцах определяли по модифицированной методике [20] сжиганием их в токе кислорода при температуре $1000^{\circ} \mathrm{C}$ с последующим поглощением продуктов сжигания 6\%-ным водным раствором пероксида водорода. Согласно работе [19], степень сульфатирования (CC) рассчитывали по формуле:

$$
\mathrm{CC}=\frac{M_{\mathrm{CA \Gamma}} W_{\mathrm{s}} / 100}{\left(M_{\mathrm{S}}-\left(M_{\mathrm{OSO}_{3} \mathrm{NH}_{4}}-M_{\mathrm{OH}}\right) W_{\mathrm{s}} / 100\right) \times 2.8} \times 100 \%
$$

= Здесь $M_{\mathrm{CA \Gamma}}, M_{\mathrm{S}}, M_{\mathrm{OSO}_{3} \mathrm{NH}_{4}}$ и $M_{\mathrm{OH}}$ - молекулярпые массы одной условной структурной единицы арабиногалактана, серы, групп $\mathrm{OSO}_{3} \mathrm{NH}_{4}$ и $\mathrm{OH}$ соответственно; $W_{\mathrm{S}}$ - содержание серы (мас. \%). Результаты для серии образцов САГ приведены в таблице.
Степень дезацетилирования (СД) хитозана устанавливали из ИК-спектров поглощения по методике [21]:

$$
\text { СД }=100 \%-\frac{A_{1655}}{A_{3430}} \times 100 / 1.33 \text {, }
$$

где $A_{1655}, A_{3430}$ - оптические плотности на соответствующих значениях волновых чисел $\left(\mathrm{cm}^{-1}\right)$.

За основу синтеза интерполимерных комплексов взяли методику, использованную ранее для хитозана и другого сульфатированного биополимера - хондроитин сульфата при близком значении $\mathrm{pH}[22,23]$.

Для приготовления раствора хитозана применяли ацетатный буфер рН $5.40 \pm 0.03$ и ионной силой 0.15 моль/л. Раствор хитозана (0.1 мас. \%) предварительно очищали от нерастворимых примесей с помощью бумажных фильтров, после чего к нему пршшнали паплям 0.1 мас. \% воднөге раствора САГ (pH $5.40 \pm 0.10)$.Дөбавлене САГпрекращали после появления опалесценции раствора, объемное соотношение растворов хитозана и арабиногалактана составляло $2: 1$. Растворы интенсивно перемешивали с помощью магнитной мешалки в течение 2 ч. Молекулярную полимерную фракцию от коллоидного раствора интерполимерных комплексов отделяли путем седиментации с помощью центрифуги "Eppendorf Mini Spin Plus" (Германия) в течение 5 мин (14500 об/мин). После удаления молекулярной фракции осадок ресуспензировался в ультразвуковой ванне "Elma Elmasonic S-30H” (Германия) в течение 30 мин при комнатной температуре в безбуферном водном растворе $(\mathrm{pH} 5.4 \pm 0.10)$. Концентрацию ИПК оценивали путем взвешивания сухого остатка: для всей серии экспериментов она составляла $0.4-0.8$ г/л. На основании средних молекулярных масс полимеров стехиометрическое соотношение макромолекул хитозана к сульфатированному арабиногалактану в ИПК примерно $1: 3$ :

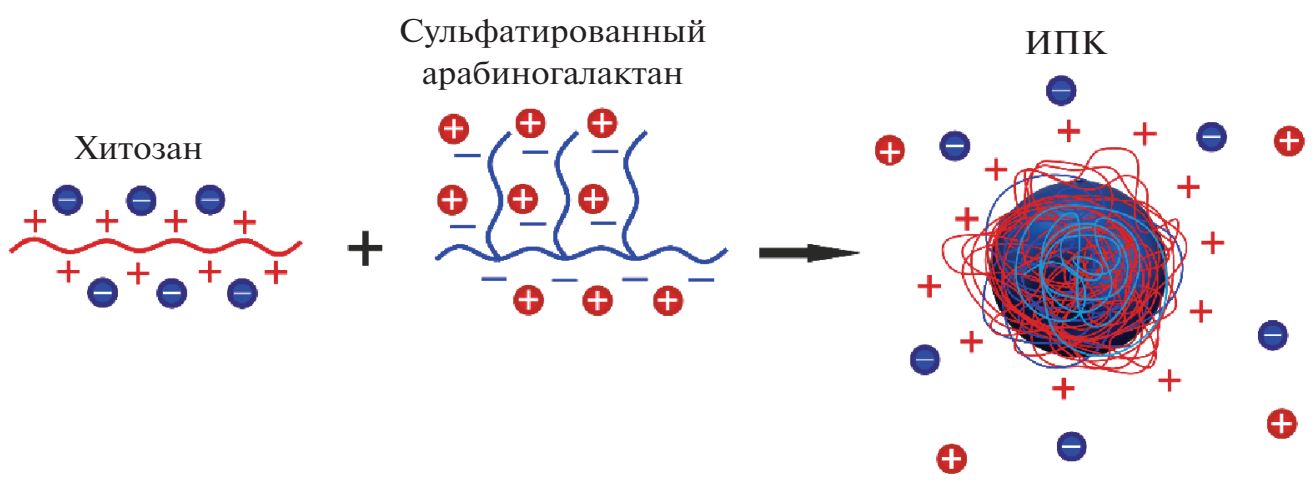

ИК-спектры хитозана, сульфатированного арабиногалактана и ИПК снимали с использова- нием ИК-фурье-спектрометра "Tensor-27" (“Bruker”, Германия) в области длин волн 400- 


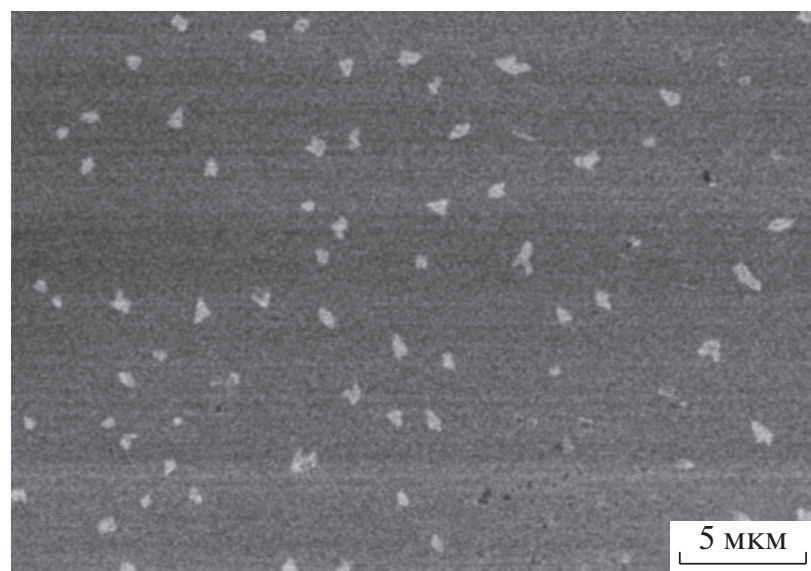

Рис. 1. Снимок со сканирующего электронного микроскопа.

$4000 \mathrm{~cm}^{-1}$. Твердые образцы для анализа готовили в виде таблеток в $\mathrm{KBr}(\sim 2$ мг образца/1000 мг KBr). ИК-спектры интерполимерных комплексов измеряли в первые три дня после синтеза.

Морфологию ИПК исследовали с применением сканирующего электронного микроскопа S-5500 (“Hitachi”, Япония). Для этого каплю разбавленного раствора ИПК в первый день после синтеза наносили на кремниевые подложки и высушивали.

Распределение частиц ИПК по размерам выполняли методом динамического рассеяния света с использованием "Zetasizer Nano ZS" ("Malvern Instruments Ltd.”, Великобритания). Угол рассеяния составлял $173^{\circ}$; длина волны лазерного излучения 532 нм. Исследования автокорреляционной функции осуществляли методом кумулянтного анализа. Каждый образец измеряли в трех сериях с двадцатью повторениями в каждой серии. Устанавливали ל-потенциал частиц на этом же приборе методом электрофоретического рассеяния света; данные собирали в четырех сериях по пятьдесят повторений в каждой.

\section{РЕЗУЛЬТАТЫ И ИХ ОБСУЖДЕНИЕ}

Для синтеза ИПК было использовано 5 образцов арабиногалактана, полученных в различных условиях и отличающихся степенью сульфатирования (таблица).

Об образовании комплексов свидетельствуют данные сканирующей электронной микроскопии (рис. 1) и ИК-спектроскопии (рис. 2). На микрограмме видны отдельно расположенные частицы ИПК, неоднородные по размерам и форме в субмикронном диапазоне.

ИК-полосы хитозана и САГ во многом схожи благодаря их подобной структуре. Типичные для полисахаридов полосы могут быть идентифицированы в областях 3435, 2921-2924 и 1047$1075 \mathrm{~cm}^{-1}$. Однако можно выделить характеристичные линии, присущие каждому полисахариду в отдельности. Для идентификации хитозана наглядными представляются полосы поглощения

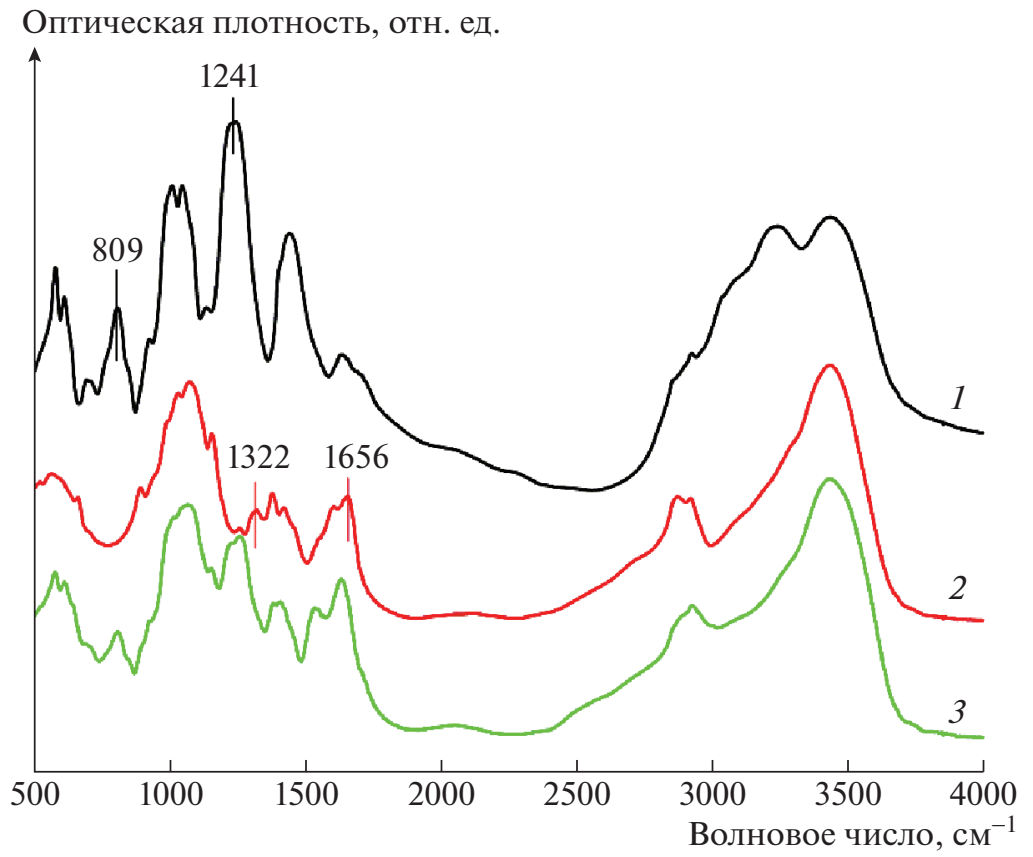

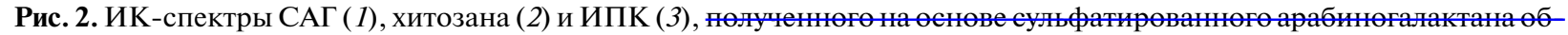
разща 2 в таблще. 


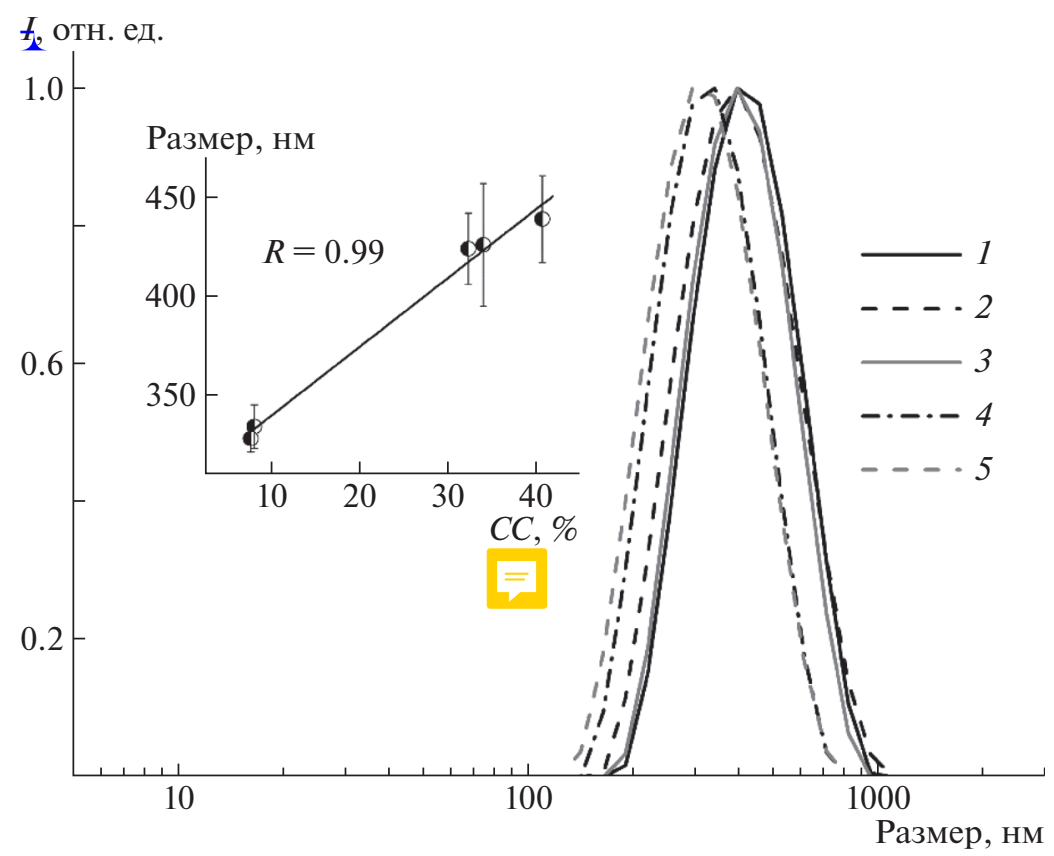

Рис. 3. Распределение частиц ИПК по размерам, синтезированных из образцов сульфатированного арабиногалактана $1-5$ в соответствии с таблицей. На вставке показана зависимость среднего размера ИПК от степени ЄАГ входящего в его состав.

для амидных групп: 1656 (амид I) и $1322 \mathrm{~cm}^{-1}$ (амид III). Показательным индикатором сульфатного замещения в арабиногалактане считается появление пика поглощения $\sim 1241 \mathrm{~cm}^{-1}$, соответствующего $\mathrm{S}=\mathrm{O}$ асимметричным валентным колебаниям и пика при $809 \mathrm{~cm}^{-1}$, характерного для валентных колебаний $\mathrm{C}-\mathrm{O}-\mathrm{S}$. В интерполимерном комплексе эти линии оказываются смещенными по сравнению с исходными компонентами из-за взаимодействий, ведущих к комплексообразованию. Характерные пики поглощения амида I и $\mathrm{S}=\mathrm{O}$ асимметричных валентных колебаний для ИПК лежат на 1633 и 1259 cм$^{-1}$ соответственно. Пик поглощения амида III исчезает, а для пика валентных колебаний $\mathrm{C}-\mathrm{O}-\mathrm{S}$ достоверного смещения не обнаружено.

Распределение частиц ИПК по размерам в первый день после синтеза показано на рис. 3. Видно мономодальное распределение частиц по размерам, максимум которого приходится на 330-440 нм. Эти данные не противоречат результатам “- икроскопических исследований. Характерн $=$ о размер частиц коррелирует со степенью сульфатирования арабиногалактана, входящего в его состав (рис. 3, вставка).

Следует отметить, что образцы ИПК как с низкой (7.7-8.1\%), так и с высокой степенью сульфатирования (32.4-40.8\%) в первый день имеют близкое значение $\zeta$-потенциала ( $\sim 40 \mathrm{MB})$, которое удовлетворяет требованиям коллоидной стабильности (ל-потенциал $>30$ мВ [24]). С течением времени происходит уменьшение размеров не только самих частиц, но и их $\zeta$-потенциала (рис. 4). При этом $\zeta$-потенциал ИПК на основе образцов 1, 2, 5 уменьшается не более чем на $15 \%$ и не преодолевает критического значения для коллоидно-стабильных частиц, а $\zeta$-потенциал ИПК на основе образцов 3 и 4 снижается на 31$42 \%$ и преодолевает этот порог. Эти результаты не коррелируют со степенью сульфатирования арабиногалактана и могут быть связаны со способом синтеза самого САГ. Так, наиболее стабильными оказались невысажденные образцы и образец, синтезированный с использованием диметилсульфоксида. Предположительно, это связано со спецификой высаживания САГ, которая может косвенно влиять на молекулярную массу выделенной фракции полисахарида, а также с остатками прекурсоров синтеза.

Уменьшение размеров частиц со временем возможно из-за их коллоидной нестабильности и выпадения в осадок наиболее крупных из них. Однако наименьшему изменению размеров оказались подвержены ИПК на основании образцов 2 и 3 (изменение 5-12\%), в то время как средний размер частиц на основе образцов 1, 4 и 5 уменьшился на 30-35\%. Это свидетельствует о более сложной связи между стабильностью размеров и $\zeta$-потенциала. Как показано в работе [25], формирование полиэлектролитных комплексов состоит из нескольких этапов: начальное формирование полиэлектролитных комплексов, 

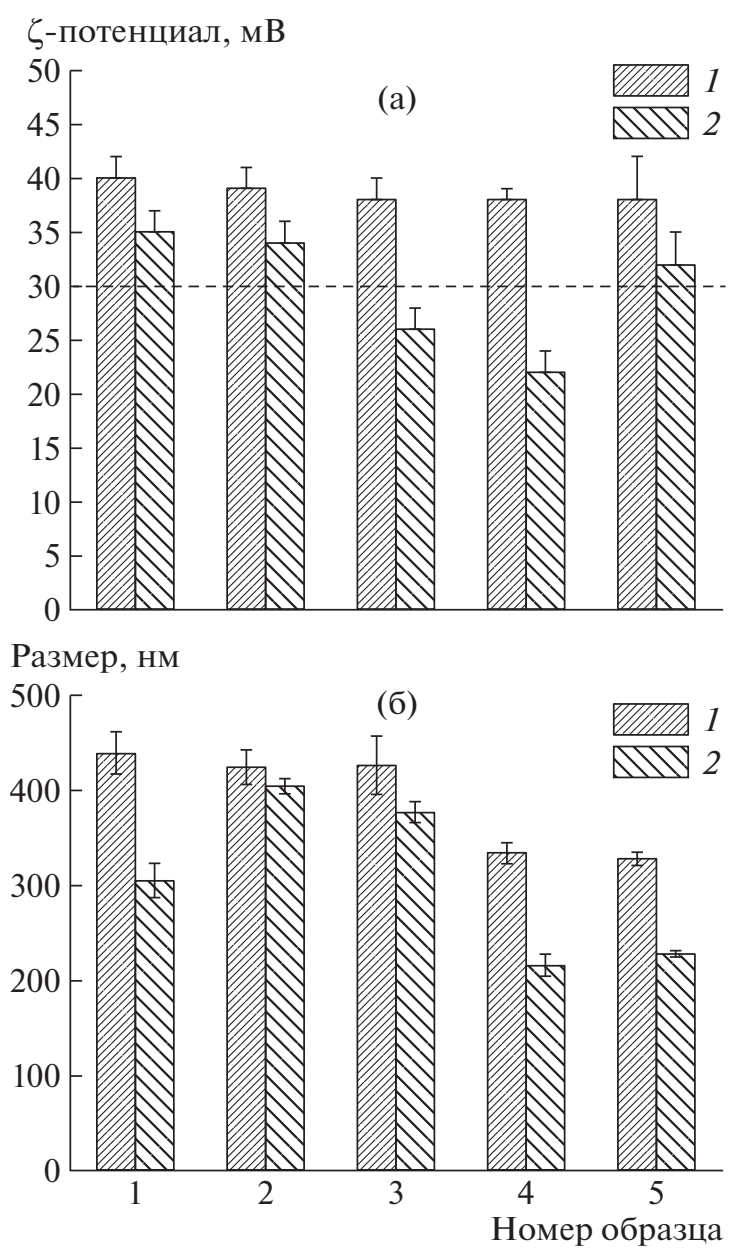

Рис. 4. Ц-Потенциал (а) и размер (б) ИПК, синтезированных из образцов сульфатированного арабиногалактана в соответствии с таблицей: $1-1$ день, $2-$ 30 дней после синтеза. Штриховой линией показан уровень, отвечающий требованию коллоидной стабильности.

формирование новых внутренних связей, межкомплексная агрегация. Разделение этих этапов является сложной задачей. Полученные в настоящей работе показатели по стабильности частиц (например, для образца 2 изменение размера и $\zeta$-потенциала за 30 дней не превышает 5 и 15\% соответственно) сопоставимы или улучшены по сравнению с другими полиэлектролитными комплексами на основе хитозана [26, 27].

Образование ИПК рассмотрено с точки зрения анализа электростатического механизма связывания двух биополимеров. Подобный количественный анализ был сделан ранее в работе [26]. Эффективность электростатического связывания зависит от количества заряженных групп биополимеров, определяемых константами диссоциации при заданных условиях $\left(\mathrm{p} K_{a}\right)$. Так, величина $\mathrm{p} K_{a}$ для аминогрупп хитозана составляет 6.2-6.8 [28]. Для сульфогрупп арабиногалактана она мо- жет быть взята равной 1.5-2.0 по аналогии с сульфогруппами хондроитин сульфата [29]. Степень диссоциации $\alpha$ полиэлектролитов выражается уравнением Хендерсона-Хассельбаха, описывающим соответствие между рН и $K_{a}$ :

$$
\mathrm{pH}=\mathrm{p} K_{a}+\lg \frac{\alpha}{1-\alpha}
$$

Согласно этому уравнению, при рН 5.4 значение $\alpha$ для хитозана составляет $75 \%$, а для САГ $78 \%$. Учитывая средние молекулярные массы полимеров, степень дезацетилирования хитозана (88\%) и степень сульфатирования арабиногалактана $(7.7 \%-40.8 \%)$, а также массовое соотношение биополимеров при смешивании, получаем оценку соотношения положительно заряженных групп хитозана к отрицательно заряженным группам САГ - от 4 : 1 до 21 : 1. Смесь противоположно заряженных полиионов привела к образованию нестехиометрических комплексов, которые обычно состоят из нейтрального ядра и избыточных полиионных цепей [30]. Поскольку положительно заряженные аминогруппы хитозана находятся в избытке по сравнению с отрицательно заряженными группами САГ, то Ц-потенциал частиц оказывается положительным.

Увеличение размера ИПК (рис. 3) и уширение распределения частиц по размерам при повышении степени сульфатирования (для образцов с низкой степенью сульфатирования ширина на полувысоте составляет 340 нм, а для высокой 410-420 нм) указывает на то, что в образовании частиц с высокой степенью сульфатирования участвует бо́льшее число молекул полисахаридов и(или) частицы имеют более рыхлую структуру. Кроме того, образование подобных комплексов зависит не только от электростатических, но и гидрофобных взаимодействий. Ранее [30] это было показано на примере комплексообразования сульфопроизводных лигнина и хитозана.

Полученные интерполимерные комплексы обладают положительным поверхностным зарядом, имеют стабильные коллоидные свойства, а также содержат в своем составе биополимеры с известной биологической активностью. Подобные системы могут быть использованы в качестве биосорбентов органических соединений или тяжелых металлов, а также систем доставки лекарств [31-33].

Авторы выражают благодарность Красноярскому региональному центру коллективного пользования “Красноярский научный центр Сибирского отделения РАН” за снятие ИК-спектров и проведение микроскопических измерений.

Работа выполнена при финансовой поддержке Российского фонда фундаментальных исследований, правительства Красноярского края и Красноярского краевого фонда науки (код проекта 1843-242003). 


\section{СПИСОК ЛИТЕРАТУРЫ}

1. Berger J., Reist M., Mayer J.M., Felt O., Gurny R. // Biopharmaceutics. 2004. V. 57. № 1. P. 35.

2. Du W.L., Xu Z.R., Han X.Y., Xu Y.L., Miao Z.G. // J. Hazard. Mater. 2008. V. 153. P. 152.

3. Wang R., Jiang X., He A., Xiang T., Zhao C. // RSC Adv. 2015. V. 5. P. 51631.

4. Prabaharan M., Mano J.F. // Drug Delivery. 2004. V. 12. P. 41.

5. Krayukhina M.A., Samoilova N.A., Yamskov I.A. // Russ. Chem. Rev. 2008. V. 77. № 9. P. 799.

6. Kumar G.V., Su C.-H., Velusamy P. // Mater. Lett. 2016. V. 12. P. 119.

7. Lai C.K., Lu Y.L., Hsieh J.T., Tsai S.C., Feng C.L., Tsai Y.S., Tsai P.C., Su H.L., Lin Y.H., Lai C.H. // Nanomedicine (Lond). 2014. V. 9. P. 803.

8. Grenha A., Gomes M.E., Rodrigues M., Santo V.E., Mano J.F., Neves N.M., Reis R.L. // J. Biomed. Mater. Res. A. 2010. V. 92. № 4. P. 1265.

9. Rodrigues S., Rosa da Costa A.M. // Grenha, Carbohydr. Polym. 2012. V. 89. P. 282.

10. Abdullah T.A., Ibrahim N.J., Warsi M.H. // Int. J. Pharm. Investig. 2016. V. 6. P. 96.

11. Santo V.E., Gomes M.E., Mano J.F., Reis R.L. // J. Tissue Eng. Regen. M. 2012. V. 6. P. 47.

12. Lallana E., De La Rosa J.R., Tirella A., Pelliccia M., Gennari A., Stratford I., Puri S., Ashford M., Tirelli N. // Mol. Pharmaceut. 2017. V. 14. P. 2422.

13. Костыро Я.Н., Силизериева О.А., Искра А.И п-трова Е.Н., Корякина Л.Б., Верещагина С.А., Фад = Т.Б., Алексеев К.В., Гуменникова Е.Н., Костыро В.В., Ганенко Т.В., Станкевич В.К., Трофимов Б.А. // Бюлл. ВСНЦ СО РАМН. 2011. Т. 80. № 4. С. 249.

14. Медведева Е.Н., Бабкин В.А., Остроухова Л.А. // Химия растительного сырья. 2003. № 1. С. 27.

15. Ehrenfreund- "I inman T., Domb A.J., Golenser J. // J. Bioact. Co $=$ it. Polym. 2003. V. 18. P. 323.

16. Vasil'eva N.Y., Levdanskya A.V., Kuznetsova B.N., Skvortsova G.P., Kazachenko A.S., Djakovitch L., Pinel C. // Russ. J. Bioorg. Chem. 2015. V. 41. № 7. P. 725 .
17. Костыро Я.А., Ковальская Г.Н. // Бюлл. ВСНЦ СО PAMH. 2008. Т. 60. № 2. С. 117.

18. Дрозд Н.Н., Кузнецова С.А., Лапикова Е.С., Давыдова А.И., Макаров В.А., Кузнецов Б.Н., Бутылкина А.И., Васильева Н.Ю., Сквориова Г.П. // Экспер. клин. фармакол. 2008. Т. 71. № 4. С. 30.

19. Черонис Н.Д., Ма Т.С. Микро- и полумикрометоды органического функционального анализа / Пер. с англ. под ред. В.А. Климовой. М.: Химия, 1973.

20. Бабкин В.А., Неверова Н.А., Медведева К.Н., Федорова T.E., Левчук A.A. // Химия растительного сырья. 2015. № 2. С. 29.

21. Czechowska- n:-kup R., Jarosińska D., Rokita B., Ulański P., I= $t k$ J.M. // Prog. Chem. Appl. Chitin. Deriv. 2012. V. 17. P. 5.

22. Slyusareva E., Gerasimova M., Plotnikov A., Sizykh A. // Colloid Int. Sci. 2014. V. 417. P. 80.

23. Slyusareva E., Gerasimova M., Slabko V., Abuzova N., Plotnikov A., Eychmiller A. // Phys. Chem. Chem. Phys. 2015. V. 16. P. 3997.

24. Boddohi S., Moore N., Johnson P.A., Kipper M.J. // Biomacromolecules. 2009. V. 10. P. 1402.

25. Kulkarni A.D., Vanjari Y.H., Sancheti K.H., Patel H.M., Belgamwar V.S., Surana S.J., Pardeshi C.V. // Artif. Cells Nanomed. Biotechnol. 2016. V. 44. P. 1615.

26. Slyusarenko N., Gerasimova M., Plotnikov A., Gaponik N., Slyusareva E. // Phys. Chem. Chem. Phys. 2019. V. 21. P. 4831.

27. Jonassen H., Kjøniksen A.-L., Hiorth M. // Biomacromolecules. 2012. V. 13. P. 3747.

28. Schmuhl R., Krieg H.M., Keizer K. // Water SA. 2001. V. 27. P. 1.

29. Chandran P., Horkay F. // Acta Biomater. 2012. V. 8. P. 3.

30. Паламарчук И.А., Бровко О.С., Бойцова Т.А., Вишнякова А.П., Макаревич Н.А. // Химия растительного сырья. 2011. Т. 2. С. 57.

31. Kyzas G.Z., Bikiaris D.N., Mitropoulosa A.C. // Polym. Int. 2017. V. 66. P. 1800.

32. Hritsu D., Dodi G., Popa M.I. // IRECHE. 2012. V. 4. № 3. P. 364.

33. Bernkop-Schnürch A., Dünnhaupt S. // Eur. J. Pharm. Biopharm. 2012. V. 81. P. 463. 